\title{
Sistem Pendukung Keputusan untuk Menentukan Siswa Berprestasi yang Layak Menjadi Siswa Teladan
}

\author{
Samuel Pojoh, Oktavian A. Lantang, Pinrolinvic D.K. Manembu \\ Teknik Informatika Universitas Sam Ratulangi \\ 110216037@student.unsrat.ac.id ,oktavian_lantang@unsrat.ac.id, pmanembu@unsrat.ac.id
}

\begin{abstract}
Saat ini hubungan Sistem Pendukung Keputusan(SPK) dengan Siswa teladan berhubungan satu dengan yang lain. Siswa Teladan merupakan sebuah kebanggaan bagi pribadi. Namun untuk menjadi siswa teladan tidaklah semua siswa berprestasi bisa mencapainya. Sistem Pendukung Keputusan (SPK) adalah bagian dari sistem informasi komputer yang berbasis pengetahuan akan manajemen pengetahuan yang dipakai untuk mendukung keputusan. Pemilihan siswa di SMA N 9 Manado dilakukan berdasarkan pengamatan dan melihat prestasi siswa tetapi tidak ada sistem yang mendukung bahwa calon yang dipilih memang layak dicalonkan maka diperlukanlah sebuah sistem untuk mendukung dan memperkuat bahwa pemilihan siswa bisa dibuktikan oleh aplikasi ini. Data didapatkan melalui guru disekolah yang berwenang menentukan siswa berprestasi yang layak menjadi siswa teladan. Metode yang digunakan dalam aplikasi ini adalah Analytical Hierarchy Process(AHP) dan menggunakan PHP untuk menentukan siswa berprestasi yang layak menjadi siswa teladan berdasarkan kriteria yang telah didapatkan dalam bentuk rangking. Aplikasi ini mempermudah guru dalam menentukan pilihan siswa teladan juga bersifat transparan serta memberikan guru dukungan yang kuat untuk mendukung keputusan yang diambil berdasarkan perangkingan yang didapat. Penerapan Sistem ini berdampak dengan bisa terdukungnya pendukung keputusan yang dilakukan manusia sehingga bisa diotomatisasi dari manual menjadi digital dan bisa diperlihatkan secara terperinci poin yang menjadi penilaian serta terjadi transparansi pemilihan siswa teladan serta pemilhan yang yang dilakukan oleh user didukung dan dibuktikan oleh sistem.
\end{abstract}

Kata Kunci : Analytical Hierarchy Process(AHP), Siswa Teladan, Sistem Pendukung Keputusan (S PK), S MA N 9 Manado

\section{PENDAHULUAN}

Pengetahuan terus berkembang dan berevolusi. Setiap orang memiliki kemampuan yang berbeda - beda akan pengetahuan. Menjadi berprestasi adalah hal yang sangat membanggakan bagi diri sendiri maupun orang lain

Siswa yang berprestasi sangat layak diajukan sebagai siswa teladan untuk mewakili sekolah. Orang yang berprestasi bias anya mengikuti perkembangan ilmu pengetahuan sehingga mempunyai peluang yang besar untuk menjadi siswa teladan. Tetapi yang dibutuhkan untuk menjadi siswa teladan bukan hanya pengetahuan ada faktor-faktor lainnya.
Berprestasi dikalangan pendidikan memiliki arti siswa itu adalah anak didik yang selalu mengikuti aturan - aturan yang di tetapkan oleh sekolah atau guru yang mendidiknya, dan selalu mempunyai kewajiban apa yang telah menjadi tugasnya sebagai siswa. Dalam penyusunan tugas akhir ini, penulis mengambil contoh kasus di lingkungan SMA Negeri 9Manado. Penulis mengangkat topik tentang pemilihan siswa berprestasi yang layak menjadi siswa teladan. Karena siswa berprestasi sangat banyak tetapi untuk mencapai kriteria agar menjadi siswa teladan tidak semua siswa berpresasi layak mendapatkannya.

Pemilihan siswa di SMA N 9 Manado hanya berdasarkan nilai juga prestasi serta kemampuan yang dimiliki sis wa tersebut dan melihat langsung siswa yang berpotensi untuk dikirimkan mewakili sekolah di ajang pemilihan siswa teladan oleh guru yang bersangkutan. Namun belum ada sistem yang bisa mendukung bahwa siswa yang dipilih memang benar dan tepat, diperlukanlah sebuah sistem untuk mendukung dan memperkuat bahwa pemilihan siswa berprestasi yang layak menjadi siswa teladan bisa dibuktikan oleh aplikasi yang dirancang ini.

\section{LANDASAN TEORI}

\section{A. Sistem Pendukung Keputusan (SPK)}

Menurut Irfan Subakti(2002) dalam Albert Andri Philip Jacobs dkk (2014) sistem pendukung keputusan adalah sistem berbasis komputer yang interaktif, yang membantu pengambil keputusan memanfaatkan data dan model untuk menyelesaikan masalah-masalah yang tak terstruktur. Sistem pendukung keputusan mendayagunakan resources individu-individu secara intelek dengan kemampuan komputer untuk meningkatkan kualitas keputusan.

Pada dasarnya Sisitem Pendukung Keputusan dirancang untuk mendukung seluruh tahap pengambilan keputusan mulai dari mengidentifikasi masalah, memilih data yang

relevan, menentukan pendekatan yang digunakan dalamproses pengambilan keputusan, sampai mengevaluasi pemilihan alternatif.)

\section{B. Siswa}

Siswa/Siswi istilah bagi peserta didik pada jenjang pendidikan dasar dan menengah. Siswa adalah komponen masukan dalam 
sistem pendidikan, yang selanjutnya diproses dalam proses pendidikan, sehingga menjadi manusia yang berkualitas sesuai dengan tujuan pendidikan nasional. Sebagai suatu komponen pendidikan, siswa dapat ditinjau dari berbagai pendekatan, antara lain: pendekatan social, pendekatan psikologis, dan pendekatan edukatif/pedagogis dengan tujuan untuk menjadi manusia yang berilmu pengetahuan, berketerampilan, berpengalaman, berkepribadian, berakhlak mulia, dan mandiri.

\section{Prestasi}

Prestasi adalah hasil yang telah dicapai seseorang dalam melakukan kegiatan. Gagne (1985:40) menyatakan bahwa prestasi belajar dibedakan menjadi lima aspek, yaitu : kemampuan intelektual, strategi kognitif, informasi verbal, sikap dan keterampilan.

\section{Teladan}

Menurut Kamus Besar Bahasa Indonesia, pengertian 'teladan' adalah sesuatu yang patut ditiru atau baik untuk dicontoh.

\section{E. Analytical Hierarchy Process(AHP)}

AHP merupakan suatu model pendukung keputusan yang dikembangkan oleh Thomas L. Saaty. Model pendukung keputusan ini akan menguraikan masalah multi faktor atau multi kriteria yang kompleks menjadi suatu hirarki, menurut Saaty (1993), hirarki didefinisikan sebagai suatu representasi dari sebuah permasalahan yang kompleks dalam suatu struktur multi level dimana level pertama adalah tujuan, yang diikuti level faktor, kriteria, sub kriteria, dan seterusnya ke bawah hingga level terakhir dari alternatif. Dengan hirarki, suatu masalah yang kompleks dapat diuraikan ke dalam kelompok-kelompoknya yang kemudian diatur menjadi suatu bentuk hirarki sehingga permasalahan akan tampak lebih terstruktur dan sistematis.

Dalam metode AHP dilakukan langkah-langkah sebagai berikut (Kadarsyah Suryadi dan Ali Ramdhani, 1998) :

1. Mendefinisikan masalah dan menentukan solusi yang diinginkan.

2. Membuat struktur hierarki yang diawali dengan tujuan utama.

3. Membuat matrik perbandingan berpasangan yang menggambarkan kontribusi relatif atau pengaruh setiap elemen terhadap tujuan atau kriteria yang setingkat di atasnya

4. Melakukan Mendefinisikan perbandingan berpasangan sehingga diperoleh jumlah penilaian seluruhnya sebanyak $\mathrm{n} . \mathrm{n}$ adalah banyaknya elemen.

\begin{tabular}{|c|l|}
\hline 1 & $\begin{array}{l}\text { Kriteria/alternatif A s ama penting dengan } \\
\text { kriteria/alternatif B }\end{array}$ \\
\hline 3 & A sedikit lebih penting dari B \\
\hline 5 & A jelas lebih penting dari B \\
\hline 7 & A sangat jelas lebih penting dari B \\
\hline
\end{tabular}

\begin{tabular}{|c|l|}
\hline & \\
\hline 9 & A mutlak lebih penting dari B \\
\hline $2,4,6,8$ & Apabila ragu-ragu anta ra dua nilai yang berdekatan \\
\hline
\end{tabular}

\section{F. Metode Perancangan Waterfall}

Menurut Pressman (2012), model waterfall adalah model klasik yang bersifat sistematis, berurutan dalam membangun software. Nama model ini sebenarnya adalah "Linear Sequential Model". Model ini sering disebut dengan "classic life cycle" atau model waterfall. Model ini termasuk kedalam model generic pada rekayasa perangkat lunak dan pertama kali diperkenalkan oleh Winston Royce sekitar tahun 1970 sehingga sering dianggap kuno, tetapi merupakan model yang paling banyak dipakai didalam Software Engineering (SE). Model ini melakukan pendekatan secara sistematis dan berurutan.

Disebut dengan waterfall karena tahap demi tahap yang dilalui harus menunggu selesainya tahap sebelumnya dan berjalan berurutan.

Fase-fase alam model waterfall menurut referensi Pressman:

\section{1) Communication}

Langkah ini merupakan analisis terhadap kebutuhan software, dan tahap untuk mengadakan pengumpulan data dengan melakukan pertemuan dengan customer, maupun mengumpulkan data-data tambahan baik yang ada di jurnal, artikel, maupun dari internet.

\section{2) Planning}

Proses planning merupakan lanjutan dari proses communication (analysis requirement). Tahapan ini akan menghasilkan dokumen user requirement atau bisa dikatakan sebagai data yang berhubungan dengan keinginan user dalam pembuatan software, termasuk rencana yang akan dilakukan.

\section{3) Modeling}

Proses modeling ini akan menerjemahkan syarat kebutuhan kesebuah perancangan software yang dapat diperkirakan sebelum dibuat coding. Proses ini berfokus pada rancangan struktur data, arsitektur software, representasi interface, dan detail (algoritma) prosedural. Tahapan ini akan menghasilkan dokumen yang disebut software requirement.

\section{4) Construction}

Construction merupakan proses membuat kode. Coding atau pengkodean merupakan penerjemahan desain dalam bahasa yang bisa dikenali oleh komputer.Programmer akan menerjemahkan transaksi yang diminta oleh user. Tahapan inilah yang merupakan tahapan secara nyata dalam mengerjakan suatu software, artinya penggunaan komputer akan dimaksimalkan dalam tahapan ini. Setelah pengkodean selesai maka akan dilakukan testing terhadap sistem yang telah dibuat tadi. Tujuan testing adalah menemukan kesalahankesalahan terhadap sistem tersebut untuk kemudian bisa diperbaiki. 
E-journal Teknik Informatika, Volume 8, No 1 (2016), ISSN : 2301-8364

\section{5) Deployment}

Tahapan ini bisa dikatakan final dalam pembuatan sebuah software atau sistem. Setelah melakukan analisis, desain dan pengkodean maka sistem yang sudah jadi akan digunakan oleh user. Kemudian software yang telah dibuat harus dilakukan pemeliharaan secara berkali kali.

\section{Metode PEngembangan Sistem}

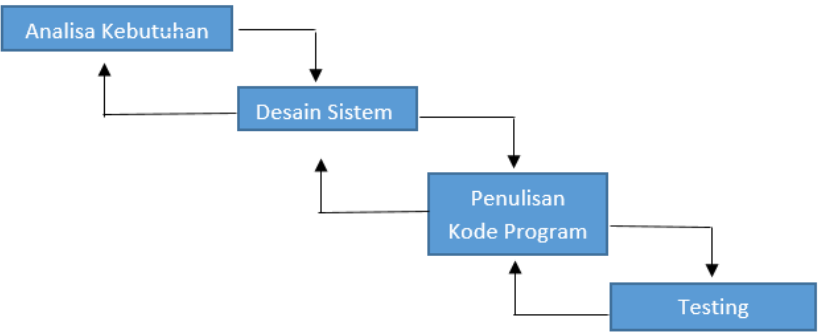

Gambar 1 Waterfall

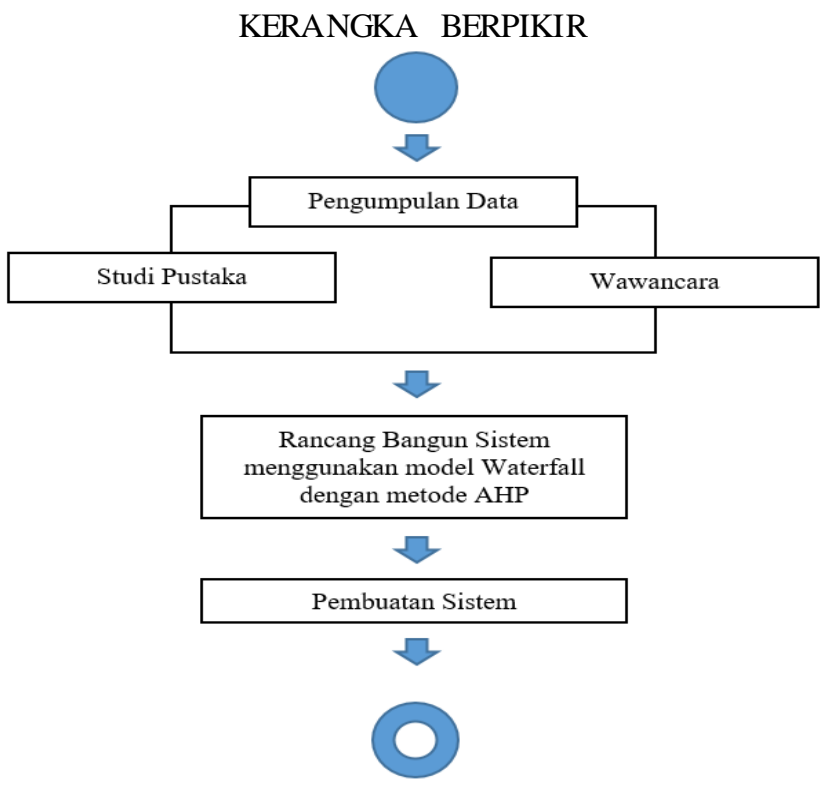

Gambar 2 Kerangka Berpikir

\section{A. Metode Pengumpulan Data}

Teknik pengumpulan data yang dilakukan adalah Studi \& Wawancara. Studi Pustaka melakukan kajian yang berkaitan dengan teori yang berkaitan dengan topik penelitian. Dalam pencarian teori, peneliti akan mengumpulkan informasi sebanyak-banyaknya dari kepustakaan yang berhubungan. Sumber-sumber kepustakaan dapat diperoleh dari: buku, jurnal, majalah, hasil-hasil penelitian (tesis dan disertasi), dan sumbersumber lainnya yang sesuai (internet, koran dll).

Wawancara yaitu melakukan tanya jawab secara langsung kepada guru bagian kesiswaan atau pihak yang dapat memberikan informasi yang kompeten, serta biasa memilih siswa berprestasi yang layak dicalonkan menjadi siswa teladan

\section{B. Use Case}

Use case diagram menggambarkan fungsionalitas yang diharapkan dari sebuah sistem. Yang ditekankan adalah "apa" yang diperbuat sistem, dan bukan "bagaimana". Sebuah use case merepresentasikan sebuah interaksi antara aktor dengan sistem

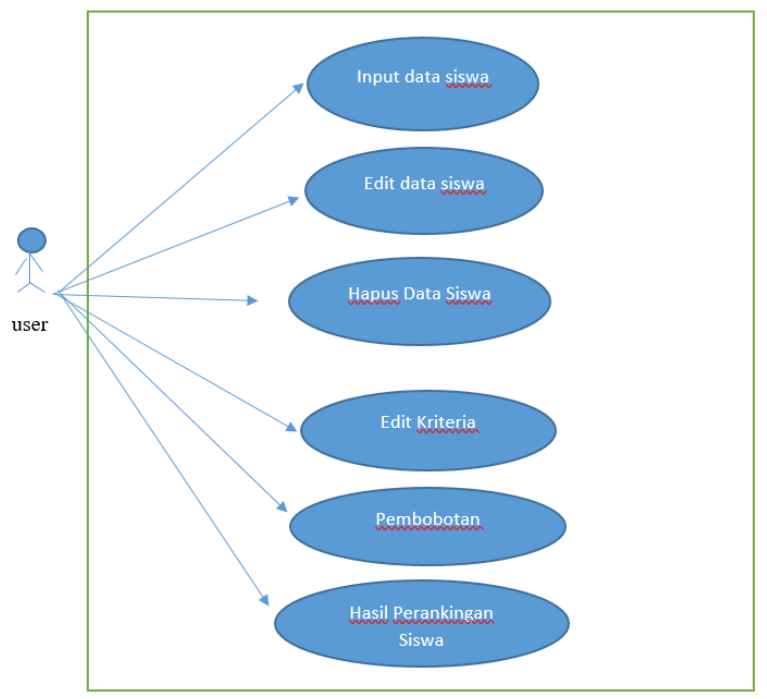

Gambar 3 Use Case Diagram

Gambar 3 menjelaskan tentang apa saja yang dapat dilakukan oleh user dalam aplikasi ini.

Use Case Description :

\begin{tabular}{|l|l|l|}
\hline Nama Use case & \multicolumn{1}{|l|}{ Input data Siswa } \\
\hline Aktor & Pengguna \\
\hline Deskripsi & Proses menambah data Siswa \\
\hline Precondition & \multicolumn{2}{|c|}{ Terdapat tombol menambah data Siswa } \\
\hline Normal Course & \multicolumn{1}{|c|}{ Kegiatan Aktor } & \multicolumn{1}{|c|}{ Sistenampilkan data } \\
\cline { 2 - 3 } & $\begin{array}{l}\text { 1. Menambah data } \\
\text { Siswa }\end{array}$ \\
\hline Alternate course & - & Siswa \\
\hline Post-condition & $\begin{array}{l}\text { Pengguna melihat data siswa yang telah } \\
\text { ditambahkan }\end{array}$ \\
\hline
\end{tabular}

Gambar 4 Use Cse Input Data Siswa

\begin{tabular}{|l|l|l|}
\hline Nama Use case & \multicolumn{2}{|l|}{ Edit data siswa } \\
\hline Aktor & Pengguna \\
\hline Deskripsi & Proses merubah data siswa yang ada \\
\hline Precondition & Pada aplikasi tersedia link mengedit data \\
\hline Normal Course & \multicolumn{1}{|c|}{ Kegiatan Aktor } & Sistem \\
\cline { 2 - 3 } & $\begin{array}{l}\text { 1. Merubah data } \\
\text { makanan yang ada }\end{array}$ & $\begin{array}{l}\text { 1. Menampilkan daftar } \\
\text { siswa yang telah diubah }\end{array}$ \\
\hline Alternate course & - & \\
\hline Post-condition & Pengguna melihat data siswa yang telah diubah \\
\hline
\end{tabular}

Gambar 5 Use Case Edit Data Siswa 
E-journal Teknik Informatika, Volume 8, No 1 (2016), ISSN : 2301-8364

\begin{tabular}{|l|l|l|}
\hline Nama Use case & \multicolumn{2}{|l|}{ Hapus data siswa } \\
\hline Aktor & Pengguna \\
\hline Deskripsi & \multicolumn{2}{|l|}{ Proses menghapus data siswa } \\
\hline Precondition & \multicolumn{2}{|c|}{ Pada aplikasi tersedia link menghapus data } \\
\hline Normal Course & \multicolumn{1}{|c|}{ Kegiatan Aktor } & \multicolumn{1}{|c|}{ Sistem } \\
\cline { 2 - 3 } & $\begin{array}{l}\text { 1. Menghapus data } \\
\text { siswa }\end{array}$ & $\begin{array}{l}\text { 1. data siswa yang ada } \\
\text { telah dihapus }\end{array}$ \\
\hline Alternate course & - & \\
\hline Post-condition & $\begin{array}{l}\text { Pengguna melihat data siswa yang ada telah di } \\
\text { hapus }\end{array}$ \\
\hline
\end{tabular}

\section{Perancangan Antar Muka}

Halaman depan dirancang sebagaimana pada gambar 5 berikut:

Gambar 6 Use Case Hapus Data Siswa

\begin{tabular}{|l|l|l|}
\hline Nama Use case & Edit kriteria \\
\hline Aktor & Pengguna \\
\hline Deskripsi & \multicolumn{2}{|l|}{ Mengubah data kriteria yang ada } \\
\hline Precondition & \multicolumn{2}{|c|}{ Pada aplikasi tersedia link mengedit data } \\
\hline Normal Course & \multicolumn{1}{|c|}{ Kegiatan Aktor } & \multicolumn{1}{c|}{ Sistem } \\
\cline { 2 - 3 } & $\begin{array}{l}\text { 1. Mengubah data } \\
\text { kriteria yang ada }\end{array}$ & $\begin{array}{l}\text { 1. Menampilkan data } \\
\text { kriteria yang telah } \\
\text { dirubah }\end{array}$ \\
\hline Alternate course & - & \\
\hline Post-condition & $\begin{array}{l}\text { Pengguna melihat data kriteria yang telah di } \\
\text { ubah }\end{array}$ \\
\hline
\end{tabular}

Gambar 7 Use Case Edit Kriteria Penilaian

\begin{tabular}{|c|c|c|}
\hline Nama Use case & \multicolumn{2}{|c|}{ Pembobotan Bobot Kriteria } \\
\hline Aktor & \multicolumn{2}{|l|}{ Pengguna } \\
\hline Deskripsi & \multicolumn{2}{|c|}{ Proses melihat bobot kriteria } \\
\hline Precondition & \multicolumn{2}{|c|}{ Pada aplikasi tersedia menu matriks } \\
\hline \multirow[t]{2}{*}{ Normal Course } & Kegiatan Aktor & Sistem \\
\hline & $\begin{array}{l}\text { 1. Melihat tabel Bobot } \\
\text { Kriteria }\end{array}$ & $\begin{array}{l}\text { 1. Menampilkan tabel } \\
\text { Bobot Kriteria }\end{array}$ \\
\hline Alternate course & \multicolumn{2}{|l|}{ - } \\
\hline Post-condition & \multicolumn{2}{|c|}{ Pengguna melihat tabel Bobot Kriteria } \\
\hline
\end{tabular}

Gambar 8 Use case edit Bobot Kriteria

\begin{tabular}{|l|l|l|}
\hline Nama Use case & \multicolumn{2}{|l|}{ Hasil Perankingan Siswa } \\
\hline Aktor & Pengguna \\
\hline Deskripsi & \multicolumn{2}{|c|}{ Proses melihat perankingan Siswa } \\
\hline Precondition & \multicolumn{2}{|c|}{ Pada aplikasi tersedia menu matriks } \\
\hline Normal Course & \multicolumn{1}{|c|}{ Kegiatan Aktor } & \multicolumn{1}{c|}{ Sistem } \\
\cline { 2 - 3 } & $\begin{array}{l}\text { 1. Melihat tabel } \\
\text { perankingan Siswa }\end{array}$ & $\begin{array}{l}\text { 1. Menampilkan tabel } \\
\text { perankingan Siswa }\end{array}$ \\
\hline Alternate course & - & \\
\hline Post-condition & Pengguna melihat tabel perankingan Siswa \\
\hline
\end{tabular}

Gambar 9 Hasil Perangkingan Siswa

\begin{tabular}{|c|c|}
\hline Menu \\
\hline Header & Beranda Data Siswa Kriteria Penilaian Bobot Kriteria Perangkingan Info \\
\hline Halaman \\
Gambaran Keseluruhan \\
Sistem pendukung Keputusan \\
Analytical Hierarchy Process \\
\\
Footer \\
\hline
\end{tabular}

Gambar 10 Halaman Depan

Pada halaman depan terdapat menu-menu sebagai berikut:

1. Header, Data Siswa,Kriteria Penilaian,Bobot Kriteria, Perangkingan,Info.

\section{Pengujian Sistem}

Aplikasi sistempendukung keputusan untuk menentukan siswa berprestasi yang layak menjadi siswa teladan menggunakan metode black box. Menurut Pressman (2002:551), Pengujian black-box berfokus pada persyaratan fungsional perangkat lunak. Dengan demikian, pengujian balck-box memungkinkan perekayasa perangkat lunak mendapatkan serangkaian kondisi input yang sepenuhnya menggunakan semua persyaratan fungsional untuk suatu program. Pengujian black-box bukan merupakan alternative dari teknik white-box, tetapi merupakan pendekatan komplementer yang kemungkinan besar mampu mengungkap kelas kesalahan daripada metode white-box. Pengujian black-box berusaha menemukan kesalahan dalam kategori sebagai berikut :

1.Fungsi - fungsi yang tidak benar atau hilang,

2.KesalahanInterface,

3.Kesalahan dalam strukturdata atau akses database eksternal,

4.Kesalahan Kinerja

5.Inisialisasi dan kesalahan terminasi 
E-journal Teknik Informatika, Volume 8, No 1 (2016), ISSN : 2301-8364

\begin{tabular}{|c|c|c|c|c|}
\hline No & Kasus & Pengujian & $\begin{array}{l}\text { Hasil yang } \\
\text { Diharapkan }\end{array}$ & $\begin{array}{c}\text { Hasil } \\
\text { Pengujian }\end{array}$ \\
\hline \multirow{2}{*}{1.} & \multirow{2}{*}{$\begin{array}{l}\text { Memeriksa } \\
\text { menu Data } \\
\text { Siswa }\end{array}$} & $\begin{array}{c}\text { Membuka menu } \\
\text { tambah siswa }\end{array}$ & $\begin{array}{l}\text { Muncul halanan } \\
\text { tambah siswa }\end{array}$ & Sukses \\
\hline & & $\begin{array}{l}\text { Merubah data } \\
\text { tambah siswa }\end{array}$ & $\begin{array}{c}\text { Data Siswa dapat } \\
\text { dirubah }\end{array}$ & Sukses \\
\hline \multirow{4}{*}{2.} & \multirow{4}{*}{$\begin{array}{c}\text { Memeriksa } \\
\text { menu kriteria } \\
\text { Penilaian }\end{array}$} & $\begin{array}{l}\text { Membuka menu } \\
\text { kriteria pemilaian }\end{array}$ & $\begin{array}{c}\text { Muncul menu } \\
\text { kriteria pemilaian }\end{array}$ & Sukses \\
\hline & & $\begin{array}{l}\text { Menambah data } \\
\text { kriteria penilaian }\end{array}$ & $\begin{array}{c}\text { Muncul tambah } \\
\text { data kriteria } \\
\text { penilaian }\end{array}$ & Sukses \\
\hline & & $\begin{array}{c}\text { Merubah data } \\
\text { kriteria penilaian }\end{array}$ & $\begin{array}{l}\text { Muncul ubah data } \\
\text { kriteria penilaian }\end{array}$ & Sukses \\
\hline & & $\begin{array}{l}\text { Menghapus data } \\
\text { kriteria penilaian }\end{array}$ & $\begin{array}{l}\text { Muncul hapus data } \\
\text { kriteria penilaian }\end{array}$ & Sukses \\
\hline 3. & $\begin{array}{l}\text { Memeriksa } \\
\text { menu bobot } \\
\text { kriteria }\end{array}$ & $\begin{array}{c}\text { Membuka menu } \\
\text { bobot kriteria }\end{array}$ & $\begin{array}{l}\text { Muncul menu } \\
\text { bobot kriteria }\end{array}$ & Sukses \\
\hline \multirow[t]{4}{*}{4.} & \multirow{4}{*}{$\begin{array}{l}\text { Memeriksa } \\
\text { menu } \\
\text { Perangkingan }\end{array}$} & $\begin{array}{l}\text { Membuka menu } \\
\text { Perangkingan }\end{array}$ & $\begin{array}{l}\text { Muncul menu } \\
\text { kriteria } \\
\text { Perangkingan }\end{array}$ & Sukses \\
\hline & & $\begin{array}{c}\text { Klik menu } \\
\text { evaluasi }\end{array}$ & $\begin{array}{c}\text { Muncul form } \\
\text { evaluasi }\end{array}$ & Sukses \\
\hline & & $\begin{array}{l}\text { Mengubah Ubah } \\
\text { Score untuk } \\
\text { Siswa dari tiap } \\
\text { Kriteria }\end{array}$ & $\begin{array}{c}\text { Muncul form Score } \\
\text { untuk Siswa dari } \\
\text { tiap Kriteria }\end{array}$ & Sukses \\
\hline & & $\begin{array}{l}\text { Membuka hasil } \\
\text { rangking }\end{array}$ & $\begin{array}{c}\text { Muncul hasil siswa } \\
\text { teladan }\end{array}$ & Sukses \\
\hline
\end{tabular}

Gambar 11 Pengujian Sistem

\section{HASIL DAN PEMBAHASAN}

Dalam pengambilan data disekolah untuk menjadi siswa berprestasi yang layak menjadi siswa teladan, didapatilah hasil seperti gambar 12, yaitu 5 Kriteria : Persentasi Religius mencapai $60 \%$ dan sisanya seperti Prestasi, Akademik, Kemampuan Bahasa Inggris dan Sikap masing - masing mendapat persentasi $10 \%$.

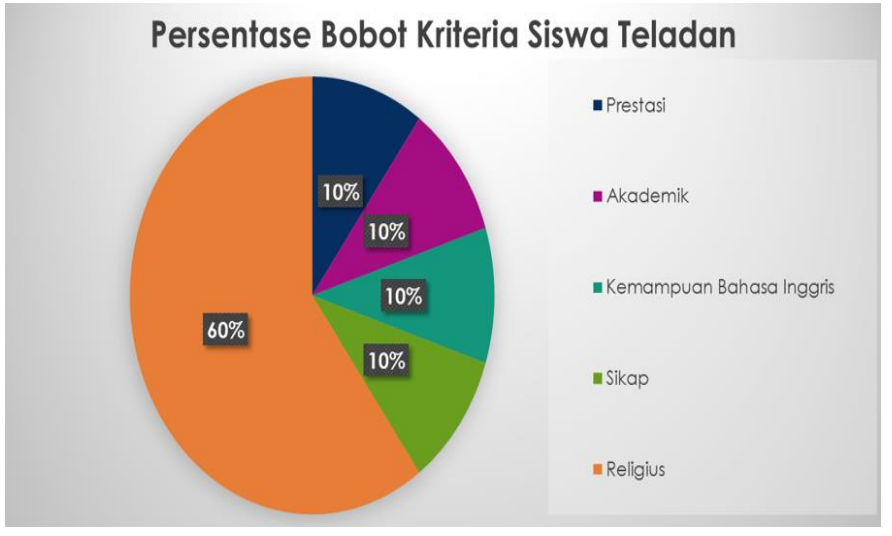

Gambar 12 Persentase Bobot Kriteria Siswa Teladan

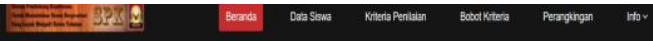

SISTEM PENDUKUNG KEPUTUSAN SISWA BERPRESTASI

Analytic Hierarchy Process (AHP) merupakan suatu model pendukung keputusan yang dikembangkan oleh Thomas L. Saaty. Model pendukung keputusan ini akan mengurakan masalah multi faktor atau multi kititeria yang kompleks menjadi suatu hirarki. Hirarki didefinisikan sebagai suatu representasi dari sebuah permasalahan yang kompleks dalam suatu strukur mutif level dimana level perlama adalah tujuan, yang dilikut level faktor, knteria, sub knteria, dan seterusnya ke bawah hingga level terakhir dari atternatifi-

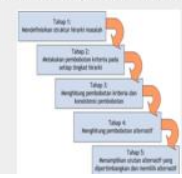

Gambar 13 Halaman Beranda

a. Kriteria Penilaian : Kriteria yang diperlukan untuk pemilihan

b. Bobot Kriteria : Bobot yang diberikan pada setiap kategori yang dipilih

c. Perangkingan : Daftar hasil perangkingan /

d. perangkuman siswa yang telah diinput

e. Info : berisi tentang bantuan, tentang dan isi.

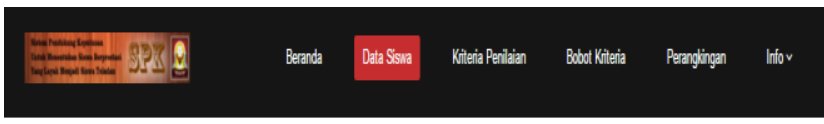

Manajemen Data Siswa

Tanteh Seran

\begin{tabular}{|c|c|c|c|c|}
\hline NS & Nama Siswa & Kelas & Alamat & Aksi \\
\hline 1001090997 & Tirsa Vlehermina home Baguna & $x$ & Neak & Eấ| |Delete \\
\hline 1401090733 & Jeremy Leonardo Yan Togas & $x$ & Ranomut & Eäl| Delete \\
\hline 1401190717 & Irene Chisty Potabuga & $x$ & Malalajang & Eẩ| Delete \\
\hline 7145 & Yolansa Lisya Görilya Rivy & $x$ & Ranomut & Eất Daltete \\
\hline
\end{tabular}


Untuk melihat data siswa yang sudah di input, pada halaman ini pengguna dapat menambahkan data siswa baru, merubah data siswa yang sebelumnya sudah di tambahkan dan juga menghapus data

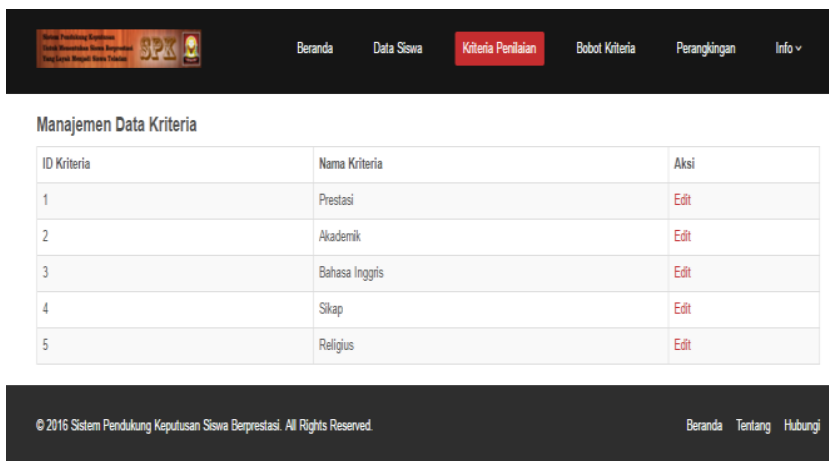

Gambar 15 Kriteria Penilaian

Halaman kriteria untuk melihat data kriteria yang sudah di masukkan ke dalam sistem, pengguna dapat mengedit data kriteria, pada halaman ini tidak ada fitur penambahan kriteria, karena pada proses perhitungan nanti akan menggunakan matriks perbandingan $5 \times 5$, jadi pada halaman ini hanya menampilkan 5 kriteria

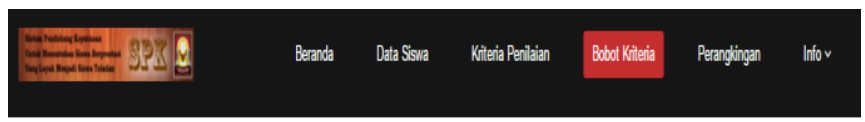

PERBANDNGAN BERPASANGAN

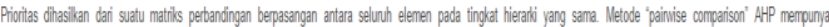

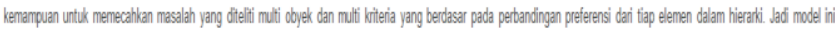

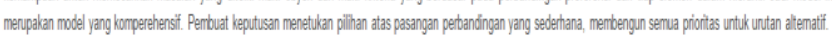

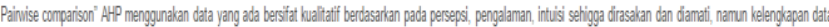
numerik tidak menunijng untuk menodelkan secrar kuartitatif

Matrik Perbandingan Berpasangan

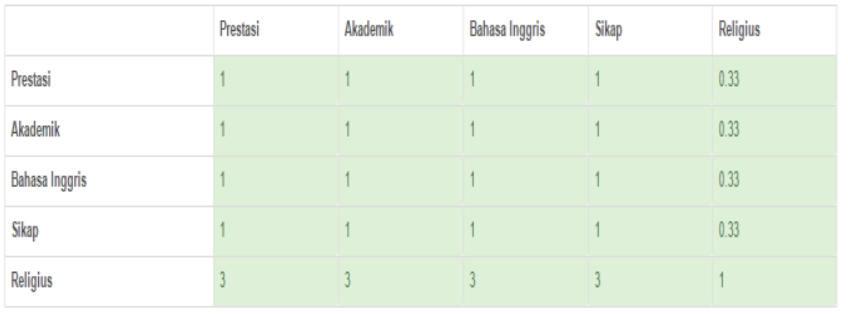

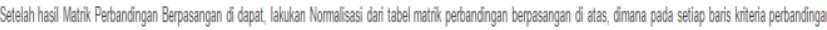
dbagi dengan total nilai kolom pada bais tersecut.

\begin{tabular}{|c|c|c|c|c|c|}
\hline & Prestasi & Akademik & Bahasa Inggris & Sikap & Religivs \\
\hline Prestasi & 0.14 & 0.14 & 0.14 & 0.14 & 0.14 \\
\hline Akademik & 0.14 & 0.14 & 0.14 & 0.14 & 0.14 \\
\hline Bahasa Inggris & 0.14 & 0.14 & 0.14 & 0.14 & 0.14 \\
\hline Sikap & 0.14 & 0.14 & 0.14 & 0.14 & 0.14 \\
\hline Religius & 0.43 & 0.43 & 0.43 & 0.43 & 0.43 \\
\hline
\end{tabular}

Gambar 16 Normalisasi Tabel \& Desimal
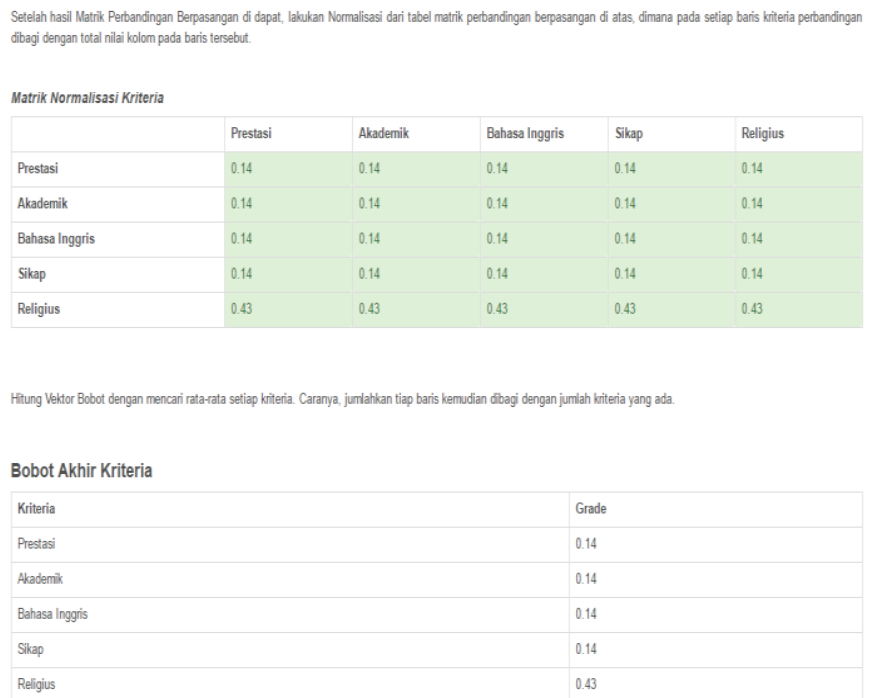

Consistency Ratio (CR):

Consistency Ratio Bisa diterima $(<=0.1)$

Lariflan Uang

Q 2016 Sistem Pendikng Keputusan Siswa Beppestasi. Al Rights Resenet

Gambar 17 Bobot Kriteria

Halaman bobot kriteria berfungsi untuk melakukan perbandingan berpasangan antara kriteria dengan kriteria lainnya, memberikan nilai bobot dari 1 - 9 berdasarkan score perbandingan dari saaty, setelah itu akan di lanjutkan dengan proses perhitungan ahp. Proses perhitungan perbandingan berpasangan, dan akan menghasilkan tabel perbandingan antar kriteria, tabel normalisasi kriteria, bobo akhir kriteria dan akan mendapatkan nilai Consistenscy Ratio (CR), jika nilai CR > 0.1 maka tidak rasio, dan harus di ulangi pembobotan, jika nilai $\mathrm{CR}<0.1$ maka nilai $\mathrm{CR}$ rasio, dan bisa dilanjutkan untuk mengevaluasi data siswa.

seluruh proses AHP terjadi disini. Dari dimulai dengan proses perbandingan berpasangan, mendesimalkan sampai mencari Consistecy ratio terdapat pada halaman ini. Bisa dilihat pada gambar 17

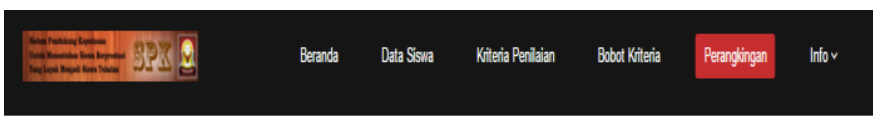

Perangkingan Siswa Berprestasi berdasarkan Bobot Kriteria

\begin{tabular}{|c|c|c|c|c|}
\hline NIS & Nama Siswa & Kelas & Alamat & Aksi \\
\hline 7145 & Yolansya Lisya Giloriya Riny & $x$ & Ranomut & Detal | Eraluasi \\
\hline 1401090717 & Irene Chisty Potabuga & $x$ & Nalabayng & Detal | Eraluasi \\
\hline 1401090733 & Jerenyy Leonardo Yan Togas & $x$ & Ranomut & Detai | Eraluasi \\
\hline 1401090997 & Tirsa Weheminina lvonne Baguna & $x$ & Neak & Detai | Eraluasi \\
\hline
\end{tabular}

\section{Hasi Rarking}




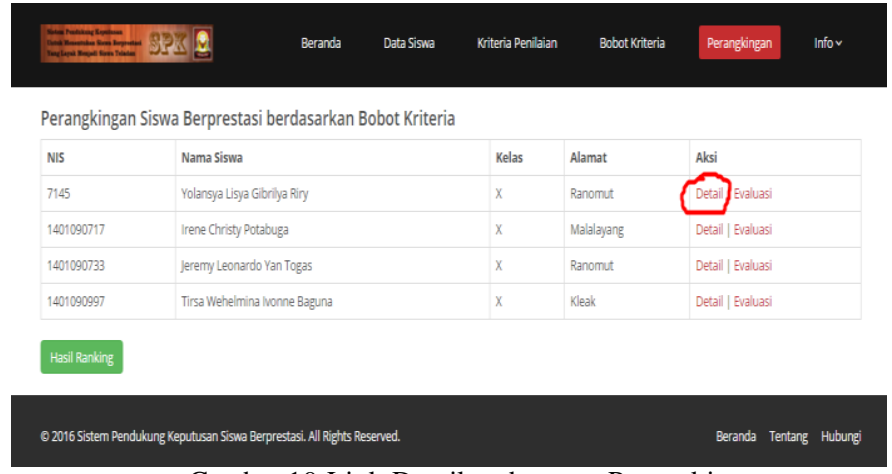

Gambar 19 Link Detail pada menu Perangkingan

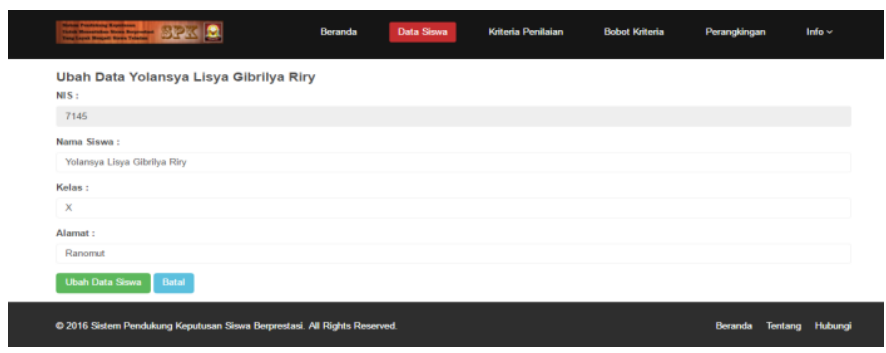

Gambar 20 Ubah Data Siswa

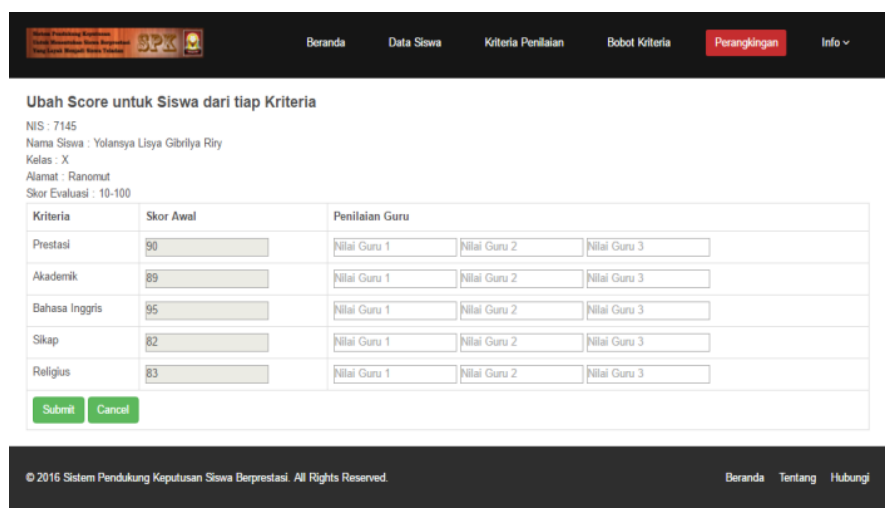

Gambar 21 Input Nilai

Berisi skor awal dan nilai dari 3 guru yang berkompeten dalam bidang masing-masing contohnya guru Bahasa inggris memberikan nilai kepada Siswa A untuk Kriteria Bahasa Inggris.

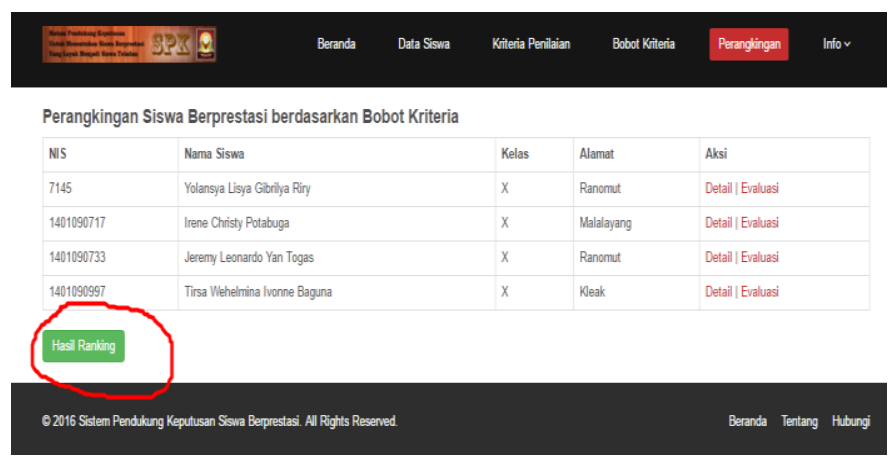

Gambar 22 Link Hasil Rangking

Setelah semua nilai untuk ke 4 sis wa telah di input oleh guru bisa dilanjutkan dengan menekan link Hasil Ranking
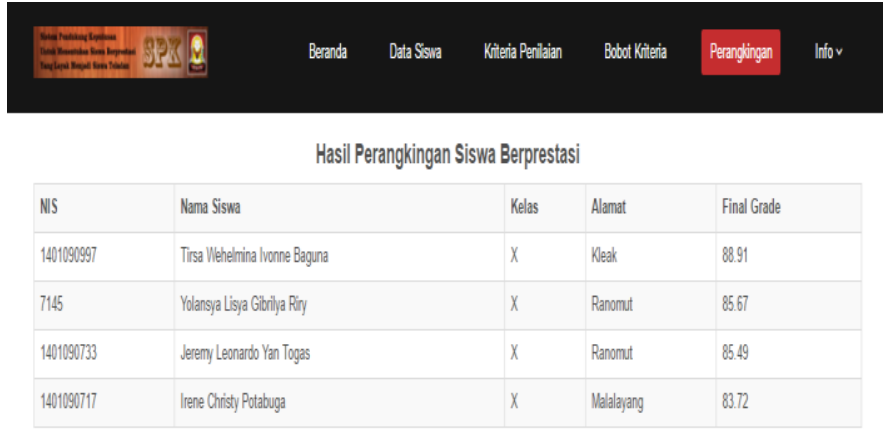

Gambar 23 Hasil Perangkingan

Setelah memilih link Hasil rangking akan ditampilkan nama nama yang memiliki nilai paling tinggi di urutan pertama diikuti terbanyak ke 2 dan ke 3.

\section{BAB V}

\section{Penutup}

5.1 Kesimpulan

Setelah melakukan penelitian mengikuti tahapan telah dihasilakan Sistem Pendukung Keputusan untuk Menentukan Siswa Berprestasi Yang layak Menjadi Siswa Teladan. Penerapan Sistem ini berdampak dengan bisa terdukungnya pendukung keputusan yang dilakukan manusia sehingga bisa diotomatisasi dari manual menjadi digital dan bisa diperlihatkan secara terperinci poin yang menjadi penilaian serta terjadi transparansi pemilihan siswa teladan serta pemilhan yang yang dilakukan oleh user ada yang mendukung.

\subsection{Saran}

-Data Siswa yang dimasukan akan berbeda tiap tahunnya karena setiap tahun pemilihan dilakukan sebaiknya untuk pemilihan berikutnya jumlah siswa yang dilibatkan lebih dari 5 orang siswa.

- Untuk setiap guru yang akan mengisi kolom nilai siswa sebaiknya pihak sekolah mengambil secara acak dan yang berkompeten agar potensikecurangan atau hanya memberi nilai yang tinggi kepada sis wa tersebut karena sudah jauh lebih dulu dikenal bisa dikurangi dengan artian setiap nilai yang diberikan guru adalah memang murni dan tidak ada campur tangan yang lain.

-Sistem yang dibuat ini sebaiknya pada pemilihan siswa teladan yang akan mewakil langsung sekolah akan lebih baik jika dipresentasikan kepada semua guru terlebih dahulu agar ada bisa lebih dimengerti dengan baik fitur - fiturnya. 
E-journal Teknik Informatika, Volume 8, No 1 (2016), ISSN : 2301-8364

\section{DAFTAR REFERENSI}

Albert Andri Philip Jacobs, Etc All. 2014 Analisa

Perancangan Sistem Pendukung Keputusan Admisi Siswa Baru menggunakan Analytical Hierarcy Process di SMA Negeri 2 Manado

Gagne .1985. The Cognitive Psychology of

School Learning. Boston: Little Brown.

Kadarsah Suryadi, DR. IR , M. Ali Ramdhani, IR. MT , 1998,

Sistem Pendukung Keputusan : Suatu Wacana

Struktural Idealisasi dan Implementasi Konsep

Pengambilan Keputusan, PT. Remaja Rosda Karya, Bandung.

Kusrini, (2009)" Konsep dan Aplikasi Sistem Pendukung

Keputusan" Andi Offset: Yogyakarta

Saaty Thomas L.,1993, Pengambilan Keputusan Bagi Para

Pemimpin, Seri Manajemen No. 134, PPM, Jakarta

Pressman Roger S., 2012, Rekayasa Perangkat Lunak, Buku 1, Pendekatan Praktis, Edisi 7, Edisi Bahasa Indonesia, Penerbit Andi, Yogyakarta.

Subakti, Irfan ,2002, Sistem Pendukung Keputusan (Decision Support System ),Institut Teknologi Sepuluh Nopember - Surabaya

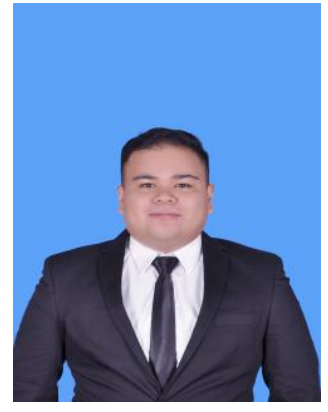

Sekilas dari penulis dengan nama lengkap Samuel Pojoh lahir di kota Manado, Provinsi Sulawesi Utara, Anak 1 dari 3 bersaudara. Pendidikan Sekolah Dasar SD Kr. Eben Haezar 02 Manado. Kemudian melanjutkan ke Sekolah Menengah Pertama SMP Kr. Eben Haezar 02 Manado Kemudian melanjutkan ke Sekolah Menengah Atas (SMA) Negeri 9 Manado. Tahun 2011 melanjutkan ke Perguruan Tinggi di Universitas Sam Ratulangi Manado dengan mengambil Jurusan Teknik Elektro dengan Program Studi Teknik Informatika. Pada tahun 2015 bulan Juni penulis membuat Skripsi dengan judul Sistem Pendukung Keputusan untuk Menentukan Siswa Berprestasi yang Layak Menjadi Siswa Teladan demi memenuhi syarat Sarjana (S1). Dengan tempat penelitian di SMA Negeri 9 Manado, dan dibimbing oleh dua dosen pembimbing yaitu Oktavian A. Lantang,ST.,MTI dan Pinrolinvic D.K. Manembu, ST.,MT. pada tanggal 29 Juni 2016 penulis resmi lulus di Teknik Informatika Universitas Sam Ratulangi Manado dan menyandang gelar Sarjana Komputer. 